\title{
SISTEM MONITORING SUHU, KELEMBABAN DAN GAS AMONIA PADA KANDANG SAPI PERAH BERBASIS TEKNOLOGI INTERNET OF THINGS (IOT)
}

\author{
Aulia Tiffani ${ }^{1)}$, Doddy Ichwana Putra ${ }^{2)}$, Tati Erlina ${ }^{3)}$ \\ 1,2,3) Sistem Komputer, Fakultas Teknologi Informasi, Universitas Andalas \\ Kampus Universitas Andalas Limau Manis, Padang \\ E-Mail : auliatiffani06@gmail.com ${ }^{1)}$; dody.ichwana@gmail.com ${ }^{2)}$; tatierlina@gmail.com $^{3)}$
}

\begin{abstract}
ABSTRAK
Dalam penelitian ini diciptakan sebuah sistem monitoring yang mengirim data tentang temperature, kelembaban, dan gas ammonia dari sebuah kandang sapi perah. Sistem ini juga memberikan notifikasi dan rekomendasi kepada pemilik untuk melakukan aksi tertentu berdasarkan data yang didapatkan dari kandang sapi tersebut. Sistem ini terdiri atas tiga komponen utama yaitu perangkat monitoring web server dan aplikasi pada perangkat bergerak. Selanjutnya, perangkat monitoring terdiri aras sebuah mikrokontroller, sensor DHT22, MQ-135 and ESP266. Mikokontroller mengirimkan datar ke web server dan perangkat bergerak secara kontinu untuk memberitahu keadaan kandang. Dari pengujian diketahui bahwa sistem dapat mengirimkan data dengan benar ke perangkat bergerak dan web server. Notifikasi tentang keadaan abnormal diberikan dalam waktu rata-rata 39 detik.
\end{abstract}

Kata Kunci : sistem monitoring, sapi perah, ESP8266, aplikasi bergerak.

\begin{abstract}
This research aims to create a monitoring system which sends temperature, humidity and ammonia gas data of a dairy stall. The system also notify and recommend the stall owner to do certain actions based on the acquired data from the stall. The system consists of three main components namely monitoring tool, web server and mobile application. Further, the monitoring tool comprises arduino uno microcontroller, DHT22 sensor, MQ-135 sensor and ESP8266. The microcontroller sends data to web server as well as to mobile phone continuously to acknowledge state of the stall. From testing result, it can be seen that system can send correct data to mobile device and web server. It delivers notification within 39 second on average in case of invalid state of the stall.
\end{abstract}

Key words : dairy cows, monitoring system, ESP8266, mobile application

\section{PENDAhULUAN}

Peternakan merupakan bidang kehidupan yang berperan penting dalam pembangunan nasional. Salah satu peternakan yang sangat menguntungkan adalah beternak sapi[1]. Peternakan sapi perah merupakan salah satu peternakan sapi yang perkembangan usahanya selalu meningkat dari tahun ke tahun[2]. Peningkatan ini sejalan dengan meningkatnya jumlah penduduk dan kesadaran masyarakat terhadap gizi seimbang akan protein hewani. Lebih dari 95\% susu yang diproduksi di Indonesia berasal dari sapi perah[2]. Namun produksi susu dalam negeri masih rendah jika dibandingkan dengan permintaan nasional. Untuk mengatasi masalah tersebut diperlukan peningkatan pemeliharaan sapi melalui inovasi teknologi perkandangan.

Sapi perah mempunyai daya tahan panas lebih rendah daripada sapi potong[3]. Karena daya tahan panas yang rendah itu, tubuh ternak sapi perah kurang bisa mempertahankan diri dari serangan panas. Sapi-sapi perah yang umumnya dipelihara di Indonesia adalah sapi perah Fries Holland (FH). Sapi perah tersebut sangat peka terhadap perubahan iklim mikro terutama suhu dan kelembaban udara. Apabila kandang sapi perah memiliki suhu tinggi dan kelembaban udara yang tidak mendukung, sapi perah akan mengalami cekaman panas yang dapat berakibat pada penurunan produktivitasnya[4]. Sapi FH menunjukkan penampilan produksi terbaik apabila ditempatkan pada suhu lingkungan 18,3oC dengan kelembaban 55\%[4]. Selain suhu dan kelembaban, kebersihan kandang dari kotoran sapi juga perlu diperhatikan. Bau yang dihasilkan dari kotoran sapi berupa gas NH3 (Amonia) dapat menyebabkan dampak yang buruk pada manusia seperti iritasi hebat pada mata, sesak nafas, nyeri dada dan gangguan sistem pernafasan lainnya[5]. 
Oleh karena itu, kotoran sapi perlu dibersihkan secara rutin oleh peternak sapi.

Kesalahan dan keterlambatan penanganan suhu dan kelembaban kandang serta kotoran sapi yang menumpuk sering dilakukan oleh peternak. Hal ini bisa disebabkan karena peternak tidak mengetahui perubahan suhu, kelembaban dan gas amonia yang dihasilkan dari kotoran sapi. Berdasarkan permasalahan dibuat sebuah sistem monitoring suhu, kelembaban dan gas amonia pada kandang sapi perah. Dengan sistem tersebut peternak diharapkan dapat memantau keadaan suhu, kelembaban dan gas metana dimana saja melalui smartphone yang terhubung ke internet. Sistem mengirim notifikasi dan rekomendasi ke smartphone berdasarkan keadaan suhu, kelembaban dan gas amonia pada kandang.

\section{TINJAUAN PUSTAKA}

\subsection{Sapi Perah}

Sapi perah merupakan hewan ternak yang menghasilkan susu sebagai produk utamanya. Sapi perah mulai dikenalkan pada rakyat Indonesia pada zaman kolonialisasi Belanda di akhir abad ke-19. Dengan semakin meningkatnya kebutuhan akan susu, permintaan akan populasi sapi perah pun akan meningkat pula. Produksi susu tidak hanya dapat ditingkatkan dengan menambah jumlah populasi sapi perah, melainkan bisa juga ditingkatkan dari sisi produktivitasnya[6].

Untuk sapi perah $\mathrm{FH}$, penampilan produksi terbaik akan dicapai pada suhu lingkungan 18,3oC dengan kelembaban 55\%. Bila melebihi suhu tersebut, ternak akan melakukan penyesuaian secara fisiologis dan secara tingkah laku (behaviour). Secara fisiologis ternak atau sapi FH yang mengalami cekaman panas akan mengalami beberapa hal seperti penurunan nafsu makan, peningkatan konsumsi minum, peningkatan temperatur tubuh dan perubahan tingkah laku[4].

Untuk menurunkan suhu dan menaikkan kelembaban kandang perlu diberikan notifikasi dan rekomendasi kepada peternak. Beberapa rekomendasi yang dapat diberikan diantaranya pemberian air minum dingin untuk ternak, menghidupkan kipas angin, penyemprotan air dingin ke seluruh tubuh ternak dan pemberian shelter di sekitar kandang[7]. Rekomendasi lain yang dapat diberikan yaitu melakukan pengkabutan dengan menggunakan air yang diubah menjadi kabut melalui nozel.

Bau yang dihasilkan dari kotoran sapi berupa gas NH3 (Amonia) dapat menyebabkan dampak yang buruk pada manusia. Gas amonia dapat menyebabkan iritasi hebat pada mata (Keraktitis), sesak nafas (Dyspnea), nyeri dada, bronchitis dan Pneumonia. Pada kadar tinggi
(30.000 ppm) dapat menyebabkan luka bakar pada kulit. Batas baku mutu dari konsentrasi gas amonia adalah sebesar 25 ppm. Beberapa rekomendasi untuk meminimalisasi gas amonia yaitu lebih sering membersihkan kotoran sapi, gunakan alat pelindung diri ketika beternak sapi, seperti masker, sarung tangan dan sepatu dan atur sirkulasi udara kandang melalui ventilasi kandang[5].

\subsection{Sistem Monitoring}

Sistem monitoring merupakan suatu proses untuk mengumpulkan data dari berbagai sumber daya. Biasanya data yang dikumpulkan merupakan data yang real time. Sistem monitoring adalah suatu sistem yang bisa digunakan untuk mengamati suatu data dari alat ukur oleh manusia dimanapun tempat dan kapanpun waktunya[8].

\subsection{Sensor DHT22}

Komponen untuk pendeteksi suhu dan kelembaban udara yang digunakan yaitu sensor DHT22. DHT22 merupakan sensor pengukur suhu dan kelembaban relatif dengan keluaran berupa sinyal digital serta memiliki 4 pin yang terdiri dari power supply, data signal, null, dan ground. DHT22 memiliki akurasi yang lebih baik daripada DHT11 dengan galat relatif pengukuran suhu 4\% dan kelembaban 18\% [9]. Perangkat sensor DHT22 dapat dilihat pada gambar 1 .

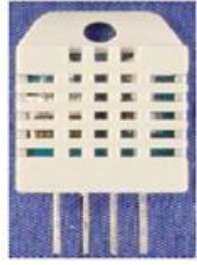

Gambar 1. Sensor DHT22[9]

\subsection{Sensor Gas MQ-135}

Sensor MQ-135 adalah sensor gas yang memiliki konduktivitas rendah jika berada di udara bersih. Konduktivitas sensor akan naik seiring dengan kenaikan konsentrasi gas. Untuk mengonversi terhadap kepekatan gas,sensor ini memerlukan suatu sirkuit listrik tambahan. Kelebihan dari sensor ini adalah memiliki kepekaan yang baik terhadap gas berbahaya (Amonia, Sulfida, Benzena) dalam berbagai konsentrasi, Masa aktif yang lama dan membutuhkan biaya yang lebih rendah[10]. Perangkat sensor MQ-135 dapat dilihat pada gambar 2.

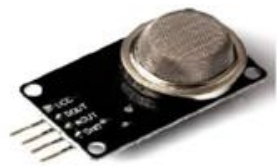


Gambar 2. Sensor gas MQ-135[10]

\subsection{Mikrokontroler (Arduino Uno)}

Arduino Uno adalah papan mikrokontroler yang berbasiskan ATmega328. Arduino jenis ini memiliki 14 pin input / output digital (dengan 6 di antaranya bisa digunakan sebagai output PWM), 6 analog input, ceramic resonator $16 \mathrm{MHz}$, koneksi USB, sambungan untuk power supply, header ICSP, dan tombol reset. Untuk menghidupkannya, mikrokontroler ini bisa disambungkan ke komputer menggunakan koneksi USB, menggunakan adaptor AC-DC, atau baterai. Gambar 3 merupakan bentuk dari arduino uno.

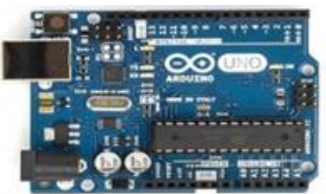

Gambar 3. Arduino uno[11]

\subsection{Internet of Things (IoT)}

Internet of Things (IoT) pertama kali diperkenalkan oleh Kevin Ashton pada tahun 1999. Meski telah diperkenalkan sejak 15 tahun yang lalu, hingga kini belum ada sebuah konsensus global mengenai definisi IoT. Namun secara umum konsep IoT diartikan sebagai sebuah kemampuan untuk menghubungkan objek-obek cerdas dan memungkinkannya untuk berinteraksi dengan objek lain, lingkungan maupun dengan peralatan komputasi cerdas lainnya melalui jaringan internet. IoT dalam berbagai bentuknya telah mulai diaplikasikan pada banyak aspek kehidupan manusia[12].

\subsection{Modul ESP8266}

ESP8266 adalah sebuah chip yang sudah lengkap dimana didalamnya sudah termasuk processor, memori dan juga akses ke GPIO. Hal ini menyebabkan ESP8266 dapat secara langsung menggantikan Arduino dan ditambah lagi dengan kemampuannya untuk mensupport koneksi wifi secara langsung. IoT (Internet Of Things) semakin berkembang seiring dengan perkembangan mikrokontroler, module yang berbasiskan Ethernet maupun wifi semakin banyak dan beragam dimulai dari Wiznet, Ethernet shield hingga yang terbaru adalah Wifi module yang dikenal dengan ESP8266[13]. Beberapa tipe ESP8266 dapat dilihat pada gambar 4.

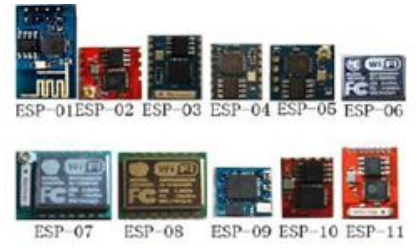

Gambar 4. Tipe ESP8266[14]

\subsection{Aplikasi Mobile}

Aplikasi Mobile adalah proses pengembangan aplikasi untuk perangkat genggam seperti PDA (Personal Digital Assistant), asisten digital perusahaan atau telepon genggam. Aplikasi ini sudah ada pada telepon selama manufaktur, atau di-download oleh pelanggan dari toko aplikasi dan dari distribusi perangkat lunak mobile platform yang lain. Sistem aplikasi mobile merupakan aplikasi yang dapat digunakan walaupun pengguna berpindah dengan mudah dari satu tempat ketempat lain lain tanpa terjadi pemutusan atau terputusnya komunikasi.[14].

\subsection{Web Server}

Web server adalah software yang menjadi tulang belakang dari world wide web (www) yang pertama kali tercipta sekitar tahun 1980an. Web server menunggu permintaan dari client yang menggunakan browser seperti Netscape Navigator, Internet Explorer, Mozilla Firefox, dan program browser lainnya. Jika ada permintaan dari browser, maka web server akan memproses permintaan itu kemudian memberikan hasil prosesnya berupa data yang diinginkan kembali ke browser. Web server, untuk berkomunikasi dengan client-nya (web browser) mempunyai protokol sendiri, yaitu HTTP (hypertext transfer protocol)[15].

\section{METODE}

\subsection{Rancangan Umum Sistem}

Berikut diagram arsitektur sistem monitoring kandang sapi perah:

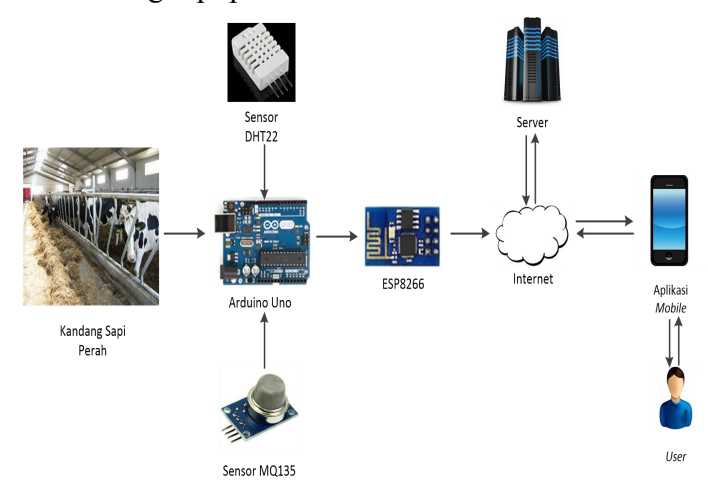

Gambar 5. Diagram arsitektur sistem 
Pada kandang terdapat komponen perangkat keras yang terdiri dari arduino uno, sensor DHT22, sensor gas MQ-135 dan ESP8266. Komponen perangkat keras tersebut akan terhubung ke aplikasi mobile melalui web server. User (peternak) akan dapat memantau suhu, kelembaban dan gas amonia pada kandang melalui aplikasi mobile.

\subsection{Perancangan Proses}

Alur fungsi sistem dapat dilihat pada top level flowchart berikut ini:

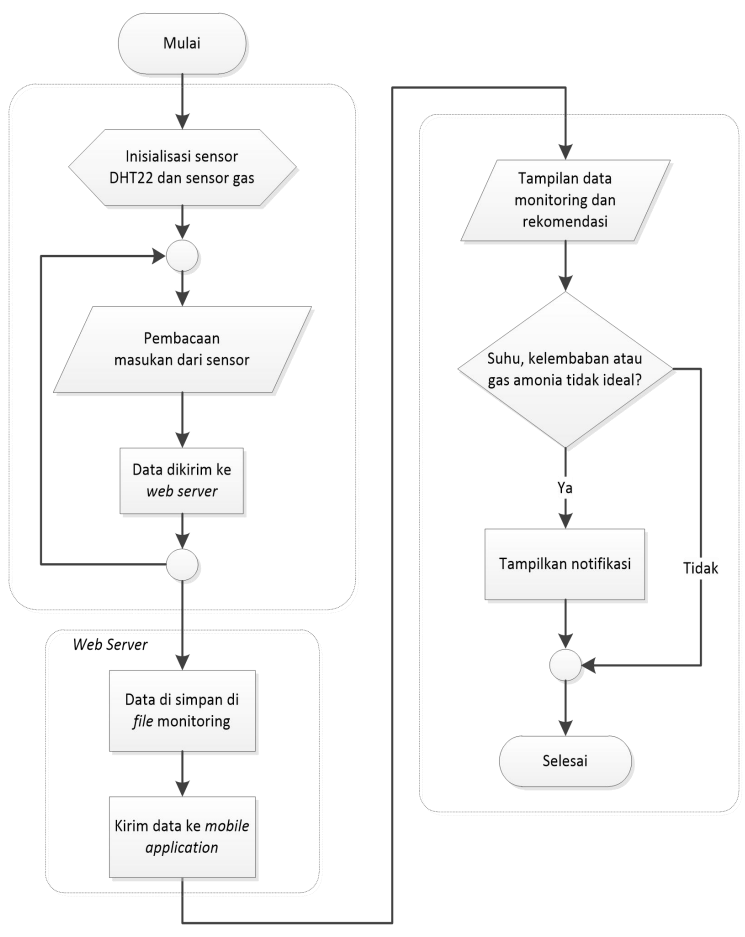

Gambar 6. Diagram top level flowchart sistem

Berikut rancangan tabel pemberian rekomendasi pada kandang sapi perah :

Tabel 1. Rancangan tabel pemberian rekomendasi

\begin{tabular}{|l|l|l|l|}
\hline No. & Data Monitoring & Nilai & Rekomendasi \\
\hline 1 & \multirow{3}{*}{ Suhu } & $0,00-16,99^{\circ} \mathrm{C}$ & Hidupkan pemanas ruangan \\
\cline { 4 - 4 } & \multirow{2}{*}{ Kelembaban } & Besar dari $22^{\circ} \mathrm{C}$ & $\begin{array}{l}\text { Hidupkan kipas angin atau } \\
\text { beri air minum dingin }\end{array}$ \\
\cline { 1 - 2 } & & $0,00-59,99 \%$ & $\begin{array}{l}\text { Hidupkan kipas angin atau } \\
\text { beri air minum dingin }\end{array}$ \\
\cline { 1 - 2 } 4 & Besar dari $80 \%$ & Hidupkan pemanas ruangan \\
\hline 5 & Gas Amonia & Besar dari $25 \mathrm{ppm}$ & Segera buang kotoran sapi \\
\hline
\end{tabular}

\subsection{Perancangan User Interface}

Adapun tampilan rancangan user interface atau antar muka dari aplikasi monitoring kandang sapi dapat dilihat pada gambar berikut :
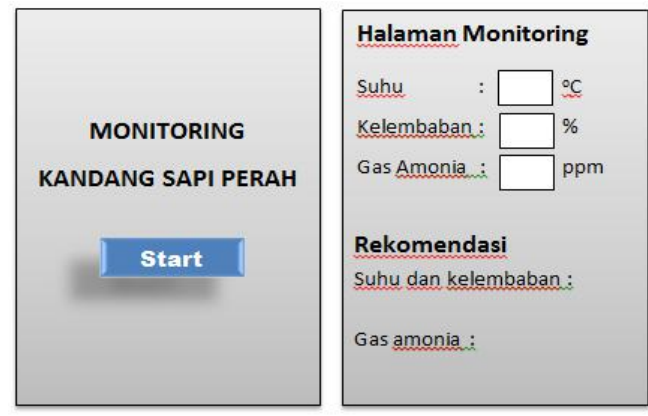

Gambar 7. Rancangan user interface monitoring kandang sapi

\section{HASIL DAN PEMBAHASAN}

\subsection{Implementasi}

\subsubsection{Implentasi Perangkat Keras}

Implementasi perangkat keras terdiri dari beberapa komponen yaitu Arduino Uno, ESP8266, Sensor DHT22, sensor gas MQ-135, breadboard dan power supply. Komponen tersebut disusun dalam sebuah karton tebal yang memiliki dimensi panjang sebesar $30 \mathrm{~cm}$, dimensi lebar sebesar 20 $\mathrm{cm}$ dan dimensi tinggi sebesar $10 \mathrm{~cm}$. Pada Gambar 8 diperlihatkan hasil implementasi perangkat keras.

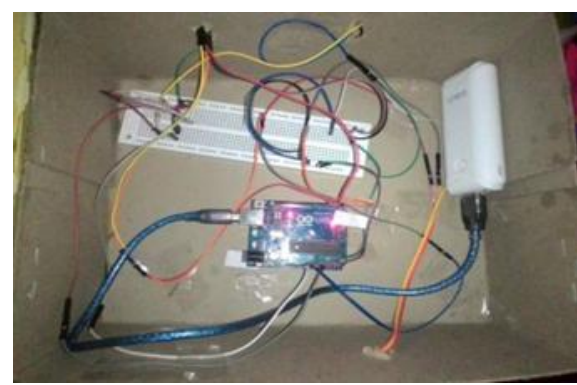

Gambar 8. Implementasi perangkat keras

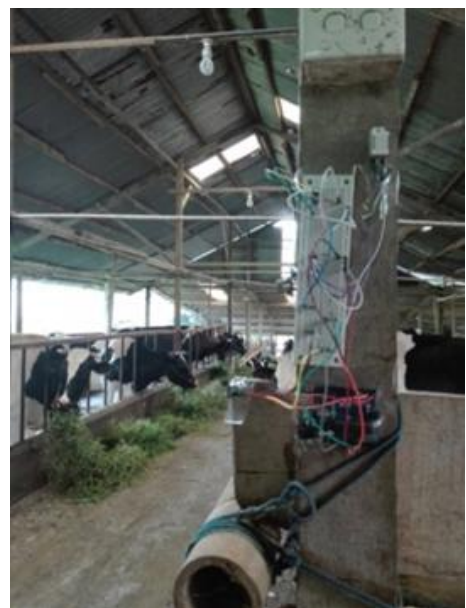

Gambar 9. Implementasi perangkat keras pada kandang sapi perah 
4.1.2 Menampilkan Data Secara Realtime

Sistem realtime adalah mekanisme pengontrolan, perekam data, pemrosesan yang sangat cepat sehingga output yang dihasilkan dapat diterima dalam waktu yang relatif sama. Pada penelitian ini sistem realtime diimplementasikan dengan melihat kesesuaian data dan kesesuaian waktu dari file penyimpanan dengan data pada aplikasi mobile. Pada gambar 10 dapat dilihat implementasi data realtime.
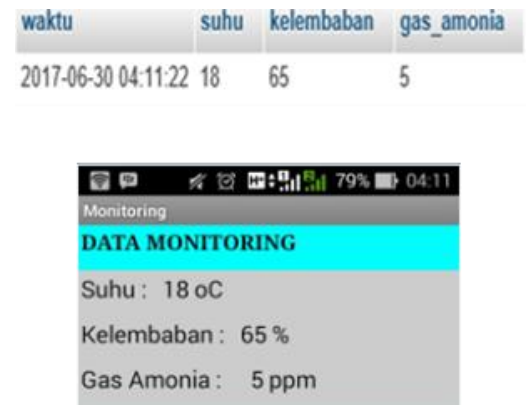

Gambar 10. Implementasi data realtime

\subsubsection{Implementasi Notifikasi Android}

Implementasi notifikasi android dilakukan dengan cara mencocokkan hasil notifikasi dengan file penyimpanan sesuai kondisi yang telah di rancang pada perancangan alur kerja mobile application. Pada gambar 11 dapat dilihat implementasi notifikasi android.
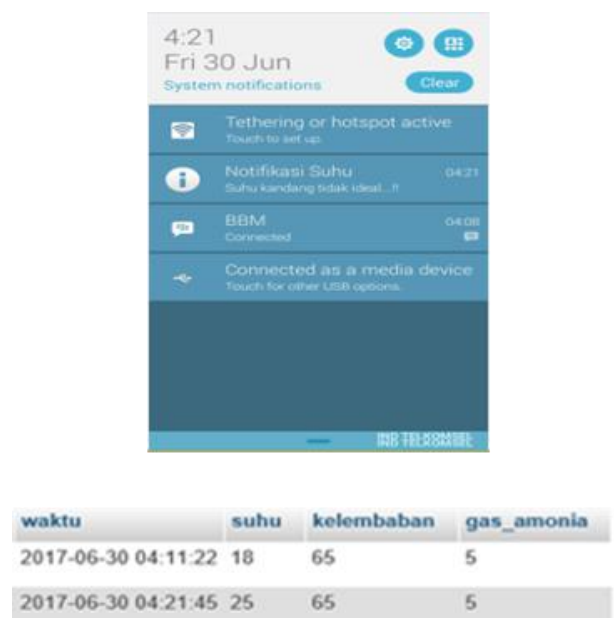

Gambar 11. Implementasi notifikasi pada android

4.1.4 Implementasi Pemberian Rekomendasi Implementasi pemberian rekomendasi dilakukan dengan cara mencocokkan hasil rekomendasi dengan file penyimpanan sesuai kondisi yang telah di rancang pada perancangan alur kerja mobile application. Pada gambar 12 dapat dilihat implementasi pemberian rekomendasi.
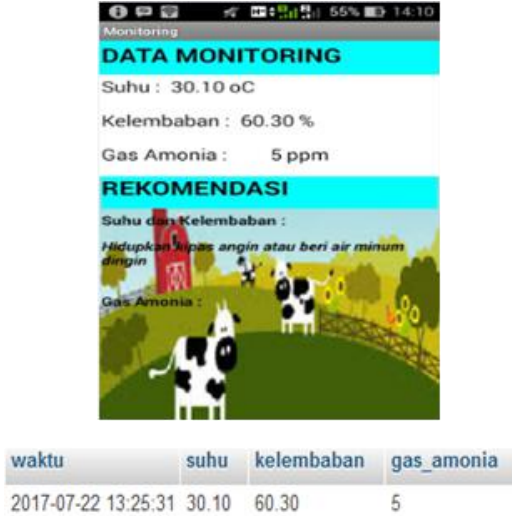

Gambar 12 Implementasi pemberian rekomendasi

\subsection{Pengujian dan Analisa}

\subsubsection{Pengujian ESP8266}

Pengujian ESP8266 dilakukan untuk menentukan apakah ESP8266 dapat terhubung ke jaringan internet atau tidak. Pengujian ini dilakukan dengan cara mengirimkan data dari ESP8266 ke web server dan didapatkan jumlah data yang terkirim dan data yang tidak terkirim. Pada tabel 2 diperlihatkan hasil pengujian dari ESP8266.

\begin{tabular}{|c|c|c|c|c|c|}
\hline $\begin{array}{c}\text { Pengiriman } \\
\text { data } \\
\text { Ke- }\end{array}$ & $\begin{array}{c}\text { Jarak } \\
(\mathrm{m})\end{array}$ & $\begin{array}{c}\text { Pairing } \\
\text { dengan } \\
\text { hotspot }\end{array}$ & $\begin{array}{c}\text { Waktu di } \\
\text { Smartphone } \\
\text { (Jammenit:detik) }\end{array}$ & $\begin{array}{c}\text { Selisih waktu } \\
\text { pengiriman data } \\
\text { ken dan ke n-1 }\end{array}$ & $\begin{array}{c}\text { Delay } \\
\text { Software } \\
\text { (Detik) }\end{array}$ \\
\hline 1 & & Berhasil & $15: 27: 46$ & 0 & 20 \\
\hline 2 & & Berhasil & $15: 28: 20$ & 34 detik & 20 \\
\hline 3 & 15 & Berhasil & $15: 28: 33$ & 13 detik & 20 \\
\hline 4 & & Berhasil & $15: 28: 54$ & 21 detik & 20 \\
\hline 5 & & Berhasil & $15: 29: 17$ & 23 detik & 20 \\
\hline 1 & & Berhasil & $15: 36: 32$ & 0 & 20 \\
\hline 2 & & Berhasil & $15: 36: 55$ & 23 detik & 20 \\
\hline 3 & 20 & Berhasil & $15: 37: 42$ & 47 detik & 20 \\
\hline 4 & & Berhasil & $15: 38: 02$ & 20 detik & 20 \\
\hline 5 & & Berhasil & $15: 38: 24$ & 22 detik & 20 \\
\hline 1 & & Berhasil & $15: 41: 36$ & 0 & 20 \\
\hline 2 & & Berhasil & $15: 42: 22$ & 46 detik & 20 \\
\hline 3 & 25 & Berhasil & $15: 42: 48$ & 36 detik & 20 \\
\hline 4 & & Berhasil & $15: 43: 06$ & 18 detik & 20 \\
\hline 5 & & Berhasil & $15: 43: 56$ & 56 detik & 20 \\
\hline
\end{tabular}

Tabel 2. Hasil pengujian ESP8266

Hasil pengujian pengriman data dari ESP8266 ke web server dapat terlihat bahwa ESP8266 dapat menerima data yang dikirim setiap percobaan dengan persentase keberhasilan sebesar 100\%. Persentase keberhasilan menunjukkan bahwa ESP8266 sudah bekerja dengan baik dalam berkomunikasi dengan jaringan internet.

\subsubsection{Pengujian Dan Analisa Sistem Secara Keseluruhan}

Telah dilakukan pengujian sebanyak 5 kali pada kandang sapi perah. Pada tabel 5 dapat dilihat hasil pengujian kesamaan data secara real-time.

Tabel 3. Hasil pengujian kesamaan data perangkat lunak dengan mobile 


\begin{tabular}{|c|c|c|c|c|c|c|c|}
\hline $\begin{array}{c}\text { Percobaan } \\
\text { ke }\end{array}$ & Data & $\begin{array}{c}\text { Data } \\
\text { dihitung } \\
\text { manual }\end{array}$ & $\begin{array}{c}\text { Data di } \\
\text { ESP8266 }\end{array}$ & $\begin{array}{c}\text { Data } \\
\text { tampilan } \\
\text { android }\end{array}$ & $\begin{array}{c}\text { Kesamaan } \\
\text { data } \\
\text { ESPS266 } \\
\text { danandroid }\end{array}$ & \begin{tabular}{|c|} 
Selish data \\
di android \\
dengan \\
manual
\end{tabular} & $\%$ enror \\
\hline 1 & \multirow{5}{*}{ Suhu } & $24,70^{\circ} \mathrm{C}$ & $24,00^{\circ} \mathrm{C}$ & $24,00^{\circ} \mathrm{C}$ & Sama & $0,70^{\circ} \mathrm{C}$ & 2,83 \\
\hline 2 & & $25,30^{\circ} \mathrm{C}$ & $24,80^{\circ} \mathrm{C}$ & $24,80^{\circ} \mathrm{C}$ & Sama & $0,50^{\circ} \mathrm{C}$ & 1,97 \\
\hline 3 & & $25,60^{\circ} \mathrm{C}$ & $24,60^{\circ} \mathrm{C}$ & $24,60^{\circ} \mathrm{C}$ & Sama & $1,00^{\circ} \mathrm{C}$ & 3,90 \\
\hline 4 & & $25,80^{\circ} \mathrm{C}$ & $25,00^{\circ} \mathrm{C}$ & $25,10^{\circ} \mathrm{C}$ & Beda & $0,80^{\circ} \mathrm{C}$ & 3,10 \\
\hline 5 & & $26,80^{\circ} \mathrm{C}$ & $26,00^{\circ} \mathrm{C}$ & $26,00^{\circ} \mathrm{C}$ & Sama & $0,80^{\circ} \mathrm{C}$ & 2,98 \\
\hline \multicolumn{7}{|c|}{ Rata-rata enror } & 2,95 \\
\hline 1 & \multirow{5}{*}{ Kelembaban } & $78 \%$ & $84,60 \%$ & $84,60 \%$ & Sama & $6,60 \%$ & 8,46 \\
\hline 2 & & $77 \%$ & $83,00 \%$ & $83,00 \%$ & Sama & $6,00 \%$ & 7,79 \\
\hline 3 & & $75 \%$ & $80,60 \%$ & $80,60 \%$ & Sama & $5,60 \%$ & 7,46 \\
\hline 4 & & $75 \%$ & $81,70 \%$ & $82,20 \%$ & Beda & $6,70 \%$ & 8,93 \\
\hline 5 & & $70 \%$ & $76,40 \%$ & $76,40 \%$ & Sama & $6,40 \%$ & 9,14 \\
\hline \multicolumn{7}{|c|}{ Rata-rataemor } & 8,35 \\
\hline 1 & \multirow{5}{*}{ Gas Amonia } & . & $16 \mathrm{ppm}$ & $16 \mathrm{ppm}$ & Sama & . & . \\
\hline 2 & & . & $17 \mathrm{ppm}$ & $17 \mathrm{ppm}$ & Sama & . & . \\
\hline 3 & & . & $16 \mathrm{ppm}$ & $16 \mathrm{ppm}$ & Sama & . & . \\
\hline 4 & & . & $16 \mathrm{ppm}$ & $16 \mathrm{ppm}$ & Sama & $\cdot$ & . \\
\hline 5 & & . & $18 \mathrm{ppm}$ & $18 \mathrm{ppm}$ & Sama & . & . \\
\hline
\end{tabular}

Terlihat dari tabel pengujian 3 ada beberapa pengujian yang tidak sama/gagal dikarenakan gangguan koneksi jaringan sehingga data tidak terkirim ke aplikasi mobile, pengujian ini memiliki persentase keberhasilan sebesar : $80 \%$

Persentase keberhasilan menunjukkan bahwa sistem dapat dipakai dengan baik dengan koneksi jaringan lancar, dimana ketika gangguan koneksi jaringan data yang dibaca adalah data yang sebelumnya. Untuk pembacaan data sensor untuk suhu diperoleh rata-rata error sebesar 2,95\% dan untuk kelembaban diperoleh rata-rata error sebesar $8,35 \%$

\subsubsection{Pengujian Menampilkan Notifikasi pada Aplikasi Mobile}

Pada pengujian ini dilakukan dengan cara menset nilai file penyimpanan ke kondisi tidak ideal lalu melihat apakah aplikasi mobile menampilkan notifikasi yang sesuai dengan keadaan kandang. Pada tabel 3 dapat dilihat hasil pengujian pemberian notifikasi pada kandang sapi perah.

Tabel 4. Hasil pengujian pemberian notifikasi

\begin{tabular}{|c|c|c|c|c|c|}
\hline $\begin{array}{c}\text { Percobaan } \\
\text { ke- }\end{array}$ & Suhu & Kelembaban & Gas Amonia & $\begin{array}{c}\text { Notifikasi yang } \\
\text { muncul }\end{array}$ & $\begin{array}{c}\text { Kebenaran } \\
\text { Notifikasi }\end{array}$ \\
\hline 1 & $24,00^{\circ} \mathrm{C}$ & $84,60 \%$ & $16 \mathrm{ppm}$ & Suhu dan kelembaban & Benar \\
\hline 2 & $24,800^{\circ} \mathrm{C}$ & $83,00 \%$ & $17 \mathrm{ppm}$ & Kelembaban & Salah \\
\hline 3 & $24,60^{\circ} \mathrm{C}$ & $80,60 \%$ & $16 \mathrm{ppm}$ & Suhu dan kelembaban & Benar \\
\hline 4 & $25,10^{\circ} \mathrm{C}$ & $82,20 \%$ & $16 \mathrm{ppm}$ & Suhu dan kelembaban & Benar \\
\hline 5 & $26,00^{\circ} \mathrm{C}$ & $76,40 \%$ & $18 \mathrm{ppm}$ & Suhu & Benar \\
\hline
\end{tabular}

Terlihat dari tabel pengujian 3 ada satu pengujian dimana notifikasi yang diberikan salah atau tidak sesuai dengan notifikasi yang seharusnya muncul, hal tersebut dikarenakan gangguan koneksi jaringan. Pengujian ini memiliki persentase keberhasilan sebesar $80 \%$.
Persentase keberhasilan menunjukkan bahwa pemberian notifikasi oleh sistem telah berjalan dengan baik, dimana kesalahan pemberian notifikasi disebabkan oleh gangguan koneksi jaringan.

\subsubsection{Pengujian Pemberian Rekomendasi pada} Aplikasi Mobile

Pada pengujian ini dilakukan dengan cara menset nilai file penyimpanan ke kondisi suhu dan kelembaban tidak normal lalu dilihat apakah aplikasi mobile menampilkan rekomendasi yang sesuai dengan keadaan kandang. Pada tabel 4 dapat dilihat hasil pengujian pemberian rekomendasi pada kandang sapi perah.

Tabel 4. Hasil pengujian pemberian rekomendasi

\begin{tabular}{|c|c|c|c|l|c|}
\hline $\begin{array}{c}\text { Percobaan } \\
\text { ke- }\end{array}$ & Suhu & Kelembaban & $\begin{array}{c}\text { Gas } \\
\text { Amonia }\end{array}$ & $\begin{array}{c}\text { Rekomendasi yang } \\
\text { muncul }\end{array}$ & $\begin{array}{c}\text { Kebenaran } \\
\text { Rekomendasi }\end{array}$ \\
\hline 1 & $24,00^{\circ} \mathrm{C}$ & $84,60 \%$ & $16 \mathrm{ppm}$ & $\begin{array}{l}\text { Hidupkan pemanas } \\
\text { ruangan }\end{array}$ & Benar \\
\hline 2 & $24,80^{\circ} \mathrm{C}$ & $83,00 \%$ & $17 \mathrm{ppm}$ & $\begin{array}{l}\text { Hidupkan pemanas } \\
\text { ruangan }\end{array}$ & Benar \\
\hline 3 & $24,60^{\circ} \mathrm{C}$ & $80,60 \%$ & $16 \mathrm{ppm}$ & $\begin{array}{l}\text { Hidupkan pemanas } \\
\text { ruangan }\end{array}$ & Benar \\
\hline 4 & $25,10^{\circ} \mathrm{C}$ & $82,20 \%$ & $16 \mathrm{ppm}$ & $\begin{array}{l}\text { Hidupkan pemanas } \\
\text { ruangan }\end{array}$ & Benar \\
\hline 5 & $26,00{ }^{\circ} \mathrm{C}$ & $76,40 \%$ & $18 \mathrm{ppm}$ & $\begin{array}{l}\text { Hidupkan kipas angin } \\
\text { dan beri air minum } \\
\text { dingin }\end{array}$ & Benar \\
\hline
\end{tabular}

Terlihat dari tabel pengujian 4 rekomendasi yang diberikan benar atau sesuai dengan notifikasi yang seharusnya muncul. Pengujian ini memiliki persentase keberhasilan sebesar $100 \%$.

\section{KESIMPULAN}

Bedasarkan perancangan, pengamatan, dan pengujian yang telah dilakukan maka dapat diambil kesimpulan bahwa sistem monitoring kandang sapi perah yang dirancang dapat menampilkan nilai suhu, kelembaban dan kadar gas amonia yang terbaru pada aplikasi mobile. Sistem ini telah mampu menampilkan notifikasi berdasarkan nilai suhu, kelembaban dan kadar gas amonia pada kandang sapi perah dengan persentase keberhasilan sebesar $80 \%$. Rekomendasi yang ditampilkan sistem telah sesuai dengan nilai suhu, kelembaban dan kadar gas amonia pada kandang sapi perah dengan persentase keberhasilan sebesar 100\%.

\section{DAFTAR PUSTAKA}

[1] Annisa, Nur dan Danusaputro, H. 2010. Sistem monitoring keamanan kandang sapi berbasis borland delphi 7.0. Jurnal Sains dan Matematika. Vol. 18 (4):124. 
[2] Djaja, W, Matondang, R.H dan Haryono. 2009. Profil Usaha Peternakan Sapi Perah di Indonesia. LIPI Press, Jakarta.

[3] Penentuan suhu kritis atas pada sapi perah dara fries holland berdasarkan respon fisiologis dengan manajemen pakan melalui simulasi Artificial Neural Network. Tugas Akhir S-2, tidak diterbitkan.

[4] Yani, A dan B.P, Purwanto. 2006. Pengaruh iklim mikro terhadap respons fisiologis sapi peranakan fries holland dan modifikasi lingkungan untuk meningkatkan produktivitasnya. Media Peternakan. Vol. 29 (1):35-37.

[5] Latief, R, E. Sutrisno, M. Hadiwidodo. 2014. Pengaruh jumlah kotoran sapi terhadap konsentrasi gas amonia (NH3) di dalam rumah. Universitas Diponegoro.

[6] Pasaribu, A, Firmansyah dan N. Idris. 2015. Analisis faktor-faktor yang mempengaruhi produksi susu sapi perah di kabupaten Karo provinsi Sumatera Utara. Jurnal Ilmu-Ilmu Peternakan. Vol. 18 (1):28-29.

[7] Fidler, A.P and Vandevender, C. 2011. Heat stress in dairy cattle. Agriculture and Natural Resource.

[8] Ohara, G.J. 2005. Aplikasi Sistem Monitoring Berbasis Web untuk Open Cluster. Universitas Telkom. Bandung.

[9] Islam, H. I, dkk. 2016. Sistem kendali suhu dan pemantauan kelembaban udara ruangan berbasis arduino uno dengan menggunakan sensor dht22 dan passive infrared. Prosiding Seminar Nasional Fisika. Vol 5:2-3

[10] Indahwati, E dan Nurhayati. 2011. Rancang bangun alat pengukur konsentrasi gas karbon monoksida(CO) menggunakan sensor gas MQ-135 berbasis mikrokontroller dengan komunikasi serial USART. UNESA.
[11] Kaur, N, R. Mahajan, D. Bagai. 2016. Air quality monitoring system based on arduino microcontroller. IJIRSET. Vol. 5 (6):9640.

[12] Meutia, E.D. 2015. Internet of things keamanan dan privasi. Universitas Syiah Kuala.

[13] Arafat. 2016. Sistem pengamanan pintu rumah berbasis internet of things (iot) dengan esp8266. Technologia. Vol. 7 (4):263.

[14] Supardi, Yuniar. 2011. Semua Bisa Menjadi Programmer Android Basic. Elex Media Komputindo, Jakarta.

[15] Nurmiati, Evy. 2012. Analisis dan perancangan web server pada handphone. Jurnal Sistem Informasi. Vol. 5(2):2. 